\title{
Örgütsel Vatandaşlık Davranışı İle İşe Tutkunluk Arasındaki İlişkinin Ölçülmesi: Bankacılık Sektörü İle İlgili Bir Araştırma
}

\section{Measuring The Relationship Between Organizational Citizenship Behavior And Job Engagement: A Study In The Banking Sector}

Edip Örücü ${ }^{\text {a }}$ Itır Hasırcı ${ }^{\text {b,* }}$

a Prof. Dr., Bandırma OnYedi Eylül Üniversitesi, İktisadi ve İdari Bilimler Fakültesi, İşletme Bölümü, 10200, Bandırma/Türkiye. ORCID: 0000-0002-3301-7496

b Yüksek Lisans Öğrencisi, Bandırma OnYedi Eylül Üniversitesi, İktisadi ve İdari Bilimler Fakültesi, İşletme Bölümü, 10200, Bandırma/Türkiye. ORCID: 0000-0002-5449-2640

\section{MAKALE BILGİSI}

Makale Geçmişi:

Başvuru tarihi: 12 Eylül 2019

Düzeltme tarihi: 12 Ocak 2020

Kabul tarihi: 30 Ocak 2020

\section{Anahtar Kelimeler:}

Örgütsel Vatandaşlık Davranışı

İşe Tutkunluk

Banka
ÖZ

Çalışanların bulundukları kuruma fayda sağlamak niyetiyle rol fazlası davranışlarda bulunmaları hali örgütsel vatandaşlık olarak tanımlanmaktadır. Çalışanın kendini işine her açıdan adaması da işe tutkunluktur. Bu çalışmanın amacı işe tutkunluğun örgütsel vatandaşlık davranışı üzerindeki etkisini ortaya koymaktır. Çalışmanın evreni Bandırma'da bulunan özel ve devlet bankalarında çalışmakta olan 250 banka personelidir. Bu sayıdan 110 çalışan ile bir anket çalışması gerçekleştirilmiştir. Örgütsel vatandaşlık davranışı ve işe tutkunluk ilişkisi güvenilirlik analizleri, korelasyon ve çoklu regresyon analizleri ile incelenmiştir. Yapılan analizler neticesinde işe tutkunluğun alt boyutlarından sadece dinçlik değişkeninin örgütsel vatandaşlık davranışı üzerinde anlamlı etkisinin olduğu tespit edilmiştir.

\section{A B S T R A C T}

Organizational citizenship is defined as the act of over role behavior of employees with the intention of providing benefits to the organization. The dedication of the employee to his/her work in all respects is the work engagement. The aim of this study is to demonstrate the effect of passion for work on organizational citizenship behavior. The population of the study is the 250 staffs of private and state banks in Bandırma. The survey was conducted with 110 employees. The relationship between organizational citizenship behavior and passion for work has been studied through reliability analyses, correlation and multiple regression analyses. The results of the study showed that only the lustre variable from the lower dimensions of passion for work had a significant effect on organizational citizenship behavior.

\section{Giriş}

$\mathrm{Bu}$ çalışmanın amacı, örgütsel vatandaşlık davranışı ve işe tutkunluk ile ilgili kavramsal bir yazın taraması gerçekleştirmek, bu kavramlara ilişkin tanımlamaları yapmak, diğer kavramlardan farklarını incelemek ve Türkçe literatüre kazandırmaktır. Örgütlerin yüksek performansla çalışabilmesi ve örgütün amaçlarına tutkuyla bağlanmış bir örgütsel davranışın oluşturulabilmesi için tartışılan konuların başında örgütsel vatandaşlık davranışı gelmektedir (Avcı, 2015: 11-26). Bu kavram örgütte yardım etmeyi ve centilmenlik davranışı ele almaktadır. Çalışanlar formal iş tanımlarından bağımsız gönüllü olarak ekstra rol davranışları sergilerlerse örgütsel vatandaşlığ gerçekleştirmiş olurlar (Meng vd., 2011: 1-5). Çünkü

\footnotetext{
* Sorumlu yazar/Corresponding author

e-posta: itir8686@gmail.com
} 
çalıştıkları örgütün devamlılığı ve verimliliği için çalışanların ekstra rol davranışları sergilemeleri gittikçe önem arz etmektedir. Örgütsel vatandaşlık davranışı gösteren bireylerin örgüt içerisindeki iş performanslarının diğer çalışma arkadaşlarına nazaran daha yüksek seviyede olduğu saptanmıştır. Ancak genel anlamda bakıldığında örgütsel vatandaşlık davranışının nasıl geliştirilebileceği, hangi kavramlar tarafindan tam olarak desteklendiği belirlenememiştir.

İşe tutkunluk ise çalışanın kendini fiziksel, zihinsel ve duygusal anlamda işine adaması ile oluşmaktadır. Bu tanımdan yola çıkarak işe tutkunluk kavramının oluşması için çalışan performansının arttırılması gerektiği savunulabilir. İşe tutkunluk psikoloji, insan kaynakları gibi kavramları da incelemeye yönelik bir kavramdır (Shuck vd., 2011: 427-445). Ayrıca bu kavram iş tatmini, örgütsel vatandaşlık, örgütsel bağlılık, işe bağlılık gibi kavramlardan da tamamen farklıdır. Tükenmişlik kavramının tamamen zıttı olarak kabul edilen işe tutkunluk enerjik olmayı, sorumluluklarını rahat bir şekilde yerine getirebilmeyi ve işini sevmeyi ele alır (Schaufeli ve Bakker, 2003). İşe tutkunluk, dinçlik, adanmışlık ve yoğunlaşma ile ilgili ruhsal bir durum olarak kabul edilir. Ayrıca geçici bir ruh hali olmayıp kısa sürede de değişen bir durum değildir. Dinçlik boyutunda kişi enerjisini harcama hususunda istekli olmalıdır. Adanmışlık boyutunda işine dört elle sarılabilmeli ve coşkuyla kendini işine adamalıdır. Yoğunlaşma boyutunda da işgören, çalışmaktan keyif alabilen, zorunluluk ile değil tamamen kendi isteği ve arzusu ile mutlu bir şekilde çalışabilen bir birey olabilmelidir. Türkiye' bu iki değişken arasında sınırlı sayıda yapılmış olup, bu çalışmalardan elde edilen sonuçlar gerçekleştirdiğimiz çalışmanın sonuçları ile örtüşmektedir.

Çalışmanın hedefi işe tutkunluk ile örgütsel vatandaşlık davranışı arasındaki ilişkiyi işe tutkunluğun alt boyutları olan dinçlik, adanmışlık ve yoğunlaşmayı da dâhil ederek ölçmektir. Yapılan analizler neticesinde işe tutkunluğun bir alt boyutu olan dinçlik ile örgütsel vatandaşlık davranışı arasında anlamlı ilişkiler tespit edilmiştir. Yine dinçlik boyutunun örgütsel vatandaşlık davranışı üzerinde anlamlı bir etkisinin olduğu görülmüştür. Elde edilen sonuçlara dayanarak yöneticiler için işe tutkunluğun dinçlik boyutunun önemi vurgulanarak, öneriler geliştirilmeye çalışılmıştır.

\section{Literatür Analizi}

\section{1. Örgütsel Vatandaşlık Davranışı}

Dennis Organ tarafindan kullanılmış olan bu olgu, iş görenlerin örgüt yararına olan davranışları kendi rızalarıyla yani isteyerek yerine getirebilmeleridir. Örgütsel vatandaşlık davranışında çalışanlar olumsuz koşullara rağmen çalıştıkları kurumun yararına olacak davranışları gerçekleştirmelerini sağlar. Organ örgütsel vatandaşlık davranışını alt boyutları ile şöyle ifade etmiştir (Organ, 1988).

Özgecilik/Yardımseverlik: Bireyin kendi işi olmamasına rağmen diğer takım arkadaşlarına yardım etmesidir. Yeni işe başlayan iş görene üst yöneticisinin yardım etmesi hali buna örnek gösterilebilir. Örneğin; göreve yeni başlamış bir iş arkadaşına fotokopi makinesini nasıl kullanacağı hususunda yardımcı olmak, işte zorlanan arkadaşına yardım etmek de bu boyuta örnek olarak gösterilebilir. Organ (1988) bu boyut ile ilgili görevi olmaksızın çalışma arkadaşına yardım eden işgörenlerin özgecilik davranışı gösterdiklerini belirtmiştir (Organ, 1988). Podsakoff ve Mackenzie de özgeciliği işgörenin, iş ile ilgili gelişebilecek olası sorunlara karşı uzman kişilere yardımcı olup, örgütün yararına davranması şeklinde tanımlamıştır (Podsakoff ve Mackenzie, 1993: 1-40).

Vicdanlılık/ Görev Bilinci: Kişinin asıl işinin dışında da çalıştığı kurumda başka işlere yardımcı olması halidir. Bu boyutta işgörenler yüksek düzeyde çalışma bilincine sahiptirler ve örgüt içinde gönüllü olarak sorumluluk alabilirler. İşgörenler bu boyut ile zamanı daima verimli kullanırlar ve böylece çalıştıkları örgüte daha fazla zaman ayırırlar. Vicdanlılığı fazla olan kişiler güvenilir, sağlam karakterli ve çalışkan bir yapıya sahiptirler.

Sportmenlik/Centilmenlik: Bireyin işyerinde olabilecek olumsuz halleri şikâyet etmeden çalışmalarına devam etmesidir. Centilmen kişiler çalıştıkları örgütte gereksiz gerginliklerden uzak durmaya çalışırlar ve çatışmalardan daima kaçınırlar. Bu boyutta örgüt için barışçıl bir ortam sağlanmış olur ve örgüt içinde olabilecek anlaşmazlıklar çözülebilir.

Nezaket: Bireylerin çalıştıkları örgütü ilgilendirecek kararlar almadan önce takım arkadaşlarını, üstlerini ve astlarını bilgilendirmesi durumudur. Örgütsel iletişimi arttıran bu kavram sorunların ortaya çıkması engeller veya olası sorunları hafifletir. Nezaket boyutu işgörenler arasında bilgi alışverişini arttıran ve bu bilgiyi herkesle paylaşmayı sağlayan bir kavramdır. Organ nezaketi, yaklaşan olaylara ve örgütsel etkinliklere dayalı olarak işgörenlerin bu konularda çalıştıkları örgütü bilgilendirmeleri ve örgüte yardım etmeleri şeklinde tanımlamıştır (Organ, 1988).

Sivil Erdem: Bireyin örgütsel faaliyetlere gönüllü olarak katılması durumudur (Kaplanseren, Örücü, 2018: 1-21). Bu kavram örgütte çalışan her işgörenin gönüllü olarak işlere katılımını açıklar (Özdevecioğlu, 2003: 117-135). Çalışanlar çalıştıkları örgütün gelişimine katkı sağlamak için ve örgütü etkileyebilecek her türlü olaya karşı kendilerini sorumlu hissederler. Kişi örgütsel politikalar, konulara katılan ve katkı sağlayan bir yapıdadır. Sivil erdem boyutuna örnek olarak kişisel e-postaları, örgütün epostalarını okumak, bireysel sorunları tartışabilmek, örgütü olumlu yönde etkileyebilecek gelişmeleri yakından takip etmek, çalıştıkları örgütte yaşanabilecek olası değişimleri de yakından takip etmek ve bu değişimlerin başkaları tarafından kabul edilmesi için çabalamayı verebiliriz.

Pozitif ruhsal yapıya sahip olan işgörenlerin daha fazla örgütsel vatandaşlık davranışı sergiledikleri görülmüştür. Dışa dönük çalışanlar her şartta uyumlu olurken içe dönük olanlar böyle tavırlar sergileyememektedir. Örgütsel vatandaşlık davranışı bir örgütte artmaya başladıkça o örgütte işgören bağlılığg oluşacaktır ve örgüt çalışılabilir bir ortam haline dönüşecektir (Çimen, 2016: 1-5). Tabi ki yöneticinin de özellikleri örgütsel vatandaşlık davranışını etkileyici bir faktör olarak belirtilmektedir. Yönetici çalışanını destekleyici tavır sergileyerek, gerektiği 
durumlarda kendisi de sorumluluk almaktan kaçınmamalıdır (Muçaoğlu, 2006).

Örgütsel vatandaşlık davranışı birçok çalışmada değişik adlarla ifade edilmektedir (Sezgin, 2005: 317-339). Örgütsel vatandaşlık tamamen içten gelen davranışlar olmakla beraber karşılık beklemeden kendini çalıştığ kuruma adama durumudur (Organ, 1998). Örgüt çalışanlarının gönüllü katılımlarıyla desteklenen bir kavramdır (Ünüvar, 2006). Örgütsel davranış ile değişik özellikleri taşıyan iş görenler arasında takım çalışması profesyonellik bazında önemlidir (Çimen, 2016: 1-5).

\section{2. İșe Tutkunluk}

İlk kez William A. Kahn'ın kullandığı bu kavram, kişilerin çalıştığı kurumda yaptığı görevlerle bireysel özellikleri arasındaki uyumun son derece önemli olduğunu ön plana çıkarmaktadır. İşe tutkunluk kavramının geliştiği çalışanlarda tükenmişlik sendromunun azaldığını belirtmişlerdir. Schaufeli, tükenmişlik sendromuna yakalanan çalışanların dahi işe tutkunluk düzeylerinin yüksek olabileceğini belirtmiştir. İşe tutkunluk olgusunda işgörenler kişisel kaynaklarını ve onlara verilen uygun koşulları değerlendirip, bunları işlerine aktarırlar (Başoda, 2017: 71-95).

İşe tutkunluk kişinin, bir işin veya işletmenin özelliklerine dair bir tutumundan ziyade, belli psikolojik ihtiyaçlarının karşılanması ile kendisi ve işyerindeki rolü arasında kurduğu kuvvetli duygusal bağ ve işe adanmışlık sonucu gelişen güdüleyici bir durumdur (Christian vd., 2011; Truss vd., 2013: 89-136). İş görenlerin kişisel ihtiyaçlarını sağlamaları açısından mühim bir kavramdır (May vd, 2004: 11-37). Stresi düşürüp, motivasyonu yükseltir. Belirtilen tanımlar karlılık, kurumun büyüyüp gelişmesi hız kazanır (Turgut, 2010: 57-89).

İşe tutkunluğu üç tane alt boyutu mevcuttur. Bunlar: dinçlik, yoğunlaşma ve adanmışlıktır.

Dinçlik, (Vigor) iş görenin çalışırken yorulmadan işine devam etmesidir (Bakker, Demerouti, Lieke, 2012). Bu kavrama göre işgören zor durumda kalsa dahi işini yapmaya devam eder. Böylece yaratıcılık hissi artar ve başarı yükselir (Salanova ve ark., 2005: 555-564). İşe tutkunluk yaşayan işgörenlerin tutumları şu şekildedir (Schaufeli vd., 2003: 1218):

-Çalışırken kendilerini enerjik hissederler,

-Ruh halleri sürekli canlıdır,

-İşe gitmek için heveslidirler,

-Uzun süre çalışabilirler ve asla sıkılmazlar,

-Olumsuz durumlarla karşılaşsalar bile dik bir duruş sergilerler.

Dinçlik boyutu işgörenler ruhsal hayatlarını etkileyen bir öneme sahiptir. Bu boyutta çalışan, her türlü zorluğa karşı dayanıklılık gösterebilecek bir yapıya sahip olarak görülmektedir. Bilgi edinmeyi seven, fedakâr olan ve çalıştığı örgütle her açıdan uyumlu çalışabilen bireyler bu boyuta dâhildir.

Yoğunlaşma, işgörenlerin işini yaparken tüm yeteneklerini ve dikkatlerini yaptıkları işe vermesi ve konsantre olması, bu durumdan da mutluluk duyması durumudur. Bu boyut motivasyon kavramında farklı olmakla beraber işgörenleri zihinsel yoğunluk gerektirdiği için etkilemektedir. Yoğunlaşma boyutunun olumlu özellikleri olduğu kadar olumsuz özellikleri de bulunmaktadır. Örneğin; işgören kendini tamamen işine verdiği zaman kişisel ilişkilerinde zorluk çekecek ve kendine zaman ayıramayacaktır. Böylece belki dinlenmeye ihtiyacı olan işgören dış dünyadan kendisini tamamen soyutlayacaktır.

Adanmışlık, bireyin yaptığı işe olan bağlılığı ile ilişkilidir (Wilmar ve ark., 2004: 294). Kendilerini işe adamış olan işgörenler işlerini daima çekici görürler ve işlerini anlamlı bulurlar. Bu durum kişinin çalıştığ ${ }_{1}$ iş ile bütünleştiğini göstermektedir. Adanmışlık boyutunu taşıyan bireylerin özellikleri şöyle sıralanabilir (Gıcı ve Tabancalı, 2011):

-Yaptıkları iş bu kişiler için daima bir anlam ifade eder,

-Her iş bu kişiler için heyecan vericidir ve çalıştıkça yaptıkları işten gurur duyarlar,

-Yaptıkları işte kariyer fırsatları yakalayacakları inancı içerisindedirler,

-Çalıştıkları örgüte sadık kalırlar,

-Örgüte faydalı olabilecekleri şekilde hareket ederler.

- Ait olma duygusunu arttıran bu boyut, işgörenlerin gönülden çalışmalarını sağlayıp, çalıştıkları örgütün amaçlarını benimsemelerini ve oluşabilecek negatif durumlara karşı daima hazırlıklı olmalarını sağlar.

\section{3. Örgütsel Vatandaşlık Davranışı ve İşe Tutkunluk İlişkisi}

İlgili literatür incelendiğinde iki değişkenin arasında sınırlı sayıda çalışma yapıldığını görülmektedir. Bu sebeple yapılacak bu çalışma ve bu çalışmaya benzer çalışmalar literatüre katkı sağlayacaktır. Bu iki kavram arası ilişkiyi incelemeye yönelik literatür analizini incelediğimizde şu sonuçlara ulaşıyoruz;

Kaplanseren ve Örücü 2018 yılında Balıkesir'deki üç yıldızlı otellere yaptıkları anket çalışmasını 134 çalışana ulaştırmış ve 127 kişiden geri dönüş almışlardır. Elde edilen veriler SPSS paket program ile değerlendirilmiştir. İşe yoğunlaşma ve adanmışlık arasında bulunan anlamlı farklılık ile cinsiyetler ve nezaket arası ilişki sonucunda kadınların erkek iş görenlere göre işlerine daha fazla katıldıkları görülmüştür. Bunların nedenleri arasında çalışılan örgütte rekabet, güç elde etme isteği gibi hususlar bulunmaktadır. Kadınların çalıştıkları örgütte işte kalıcı olabilmek adına işlerine dört elle sarıldıkları görülmüştür (Kaplanseren ve Örücü, 2018: 1-21).

Çankır 2016 yılındaki çalışmasında Kırklareli Üniversitesinde çalışan 303 akademisyen arasında anket tekniğini kullanmak suretiyle çalışmasını gerçekleştirmiştir. Çalışmanın temel amacı işe tutkunluğun örgütsel vatandaşlık davranışı üzerindeki etkisini ölçmektir. Korelasyon analizi sonucuna göre belirttiğimiz iki değişken arasında olumlu bir ilişki olduğu belirlenmiştir. Regresyon analizi sonucunda işe tutkunluğun örgütsel vatandaşlik davranışının önemli bir bölümünü açıkladığı, alt boyutlar olarak incelendiğinde dinçlik boyutunun diğer boyutlara göre daha çok etkilendiğini saptamıştır. Sonuçta dinçlik 
duygusuna sahip akademisyenlerin daha çok örgütsel vatandaşlık davranışı sergiledikleri belirlenmiştir (Çankır, 2016: 766-773).

2016 y1lında Çin'de 12 otel kapsamında 303 işgören ile yapılan bir diğer çalışmada belirtilen iki değişken arasında olumlu bir ilişkiye ulaşılmıştır (Lyu, 2016: 69-80).

Runhaar, Konermann ve Sanders tarafından 2013 yılında yapılan ve 211 öğretmen üzerinde sürdürülen çalışmada işe tutkunluğun örgütsel vatandaşlığa etki ettiği belirlenmiştir. Çalışma işe tutkunluğun işletme açısından pozitif etkiler yarattığı ve örgütsel vatandaşlığı olumlu etkilediği sonucunu getirmiştir (Ruhnaar vd., 2013: 99-108).

Kataria, Garg ve Rastogi 2013 yılında 13 farklı örgütte ve 278 işgören arasında yaptıkları çalışmada çalışma ortamının işgörenin daha rahat olabileceği şekilde düzenlendiğinde işe tutkunluğun artacağını, işe tutkunluk arttığında örgütsel vatandaşlı̆̆ da pozitif yönde etkileyeceğini belirtmişlerdir (Kataria vd., 2013: 217-242).

\section{Araştırmanın Yöntemi ve Hipotezler}

$\mathrm{Bu}$ çalışmanın amacı belirtilen iki değişkenin arasındaki ilişkiyi ortaya koymaktır ve elde edilecek sonuçlar 1şı̆̆ında örgütlere belirli düzeylerde tavsiyelerde bulunulacaktır.

Araştırmanın evrenini Balıkesir'in Bandırma ilçesindeki mevcut 11 bankanın 250 çalışanı oluşturmaktadır. Yapılan anketlerden 110 tanesinden kesin dönüş sağlanmış olup, çalışmanın örneklemi 110 kişiden oluşmaktadır. Çalışanların 68'i kadın ve 42'si erkektir. Çalışmada anket tekniği kullanılmıştır. Elde edilen veriler bir paket program yardımıyla değerlendirilerek analiz edilmiştir.

Araştırmada işe tutkunluğu ölçmek için Schaufeli tarafından geliştirilen Utrecht Work Engagement Scale ölçeği kullanılmıştır. Örgütsel vatandaşlık davranışı ölçeği de Türkçe'ye Harun Şeşen ve Nejat Basım tarafindan, Podsakoff ve Mackenzie çalışmasından uyarlanan 19 soruluk, (2000) senesinde yapılan çalışmadan uyarlanmıştır. Örneklem sayısı 200'ün altında olduğu için faktör analizi uygulanamamıştır (Gürbüz ve Şahin, 2017).

Araştırmanın hipotezleri şu şekildedir:

$\mathbf{H}_{1}$ : İşe tutkunluğun bir alt boyutu olan dinçlik ile örgütsel vatandaşlık arasında anlamlı bir ilişki vardır.

H2: İşe tutkunluğun bir alt boyutu olan adanmışlık ile örgütsel vatandaşlık davranışı arasında anlamlı bir ilişki vardir.

H3: İşe tutkunluğun bir alt boyutu olan yoğunlaşma ile örgütsel vatandaşlık davranışı arasında anlamlı bir ilişki vardir.

H4: İşe tutkunluğun örgütsel vatandaşlık davranışı üzerinde anlamlı bir etkisi vardır.

$\mathbf{H}_{4 a}$ : İşe tutkunluğun bir alt boyutu olan dinçliğin örgütsel vatandaşlık davranışı üzerinde anlamlı bir etkisi vardır.

H4b: İşe tutkunluğun bir alt boyutu olan yoğunlaşmanın örgütsel vatandaşlık davranışı üzerinde anlamlı bir etkisi vardir.
H4c: İşe tutkunluğun bir alt boyutu olan adanmışlığın örgütsel vatandaşlık davranışı üzerinde anlamlı bir etkisi vardir.

\section{Araștırmanın Bulguları}

Aşağıdaki tabloda işe tutkunluk, alt boyutları ve örgütsel vatandaşlık davranışı için Cronbach's Alpha değerleri verilmiştir.

Tablo 1: Güvenilirlik Analizleri

\begin{tabular}{lll} 
& Cronbach's Alfa & $\begin{array}{l}\text { Örneklem } \\
\text { Sayısı }\end{array}$ \\
\hline Dinçlik &, 745 & 110 \\
Adanmışık &, 722 & 110 \\
Yoğunlaşma &, 826 & 110 \\
İşe Tutkunluk &, 848 & 110 \\
Örgütsel Vatandaşlık &, 755 & 110 \\
\hline
\end{tabular}

Güvenilirliklerini incelediğimizde işe tutkunluk için 0,848 bulunan değer neticesinde ölçeğin güvenilir olduğu sonucuna ulaşılabilir. Örgütsel vatandaşlık ölçeğinin Cronbach's Alpha değeri ise 0,755 bulunmuştur ve bulunan tüm değerler gibi bu değerde güvenilir kabul edilmiştir. İşe tutkunluk ölçeğinin her bir alt boyutu için Cronbach's Alpha değerleri belirtilmiştir.

Tablo 2: Katılımc1lara Ait Demografik Bilgiler

\begin{tabular}{|c|c|c|c|}
\hline Değişken & & Frekans & Yüzde (\%) \\
\hline \multirow[t]{2}{*}{ Cinsiyet } & Kadın & 68 & 61,8 \\
\hline & Erkek & 42 & 38,2 \\
\hline \multirow[t]{5}{*}{ Yaş } & 18-24 & 3 & 2,7 \\
\hline & $25-31$ & 31 & 28,2 \\
\hline & $32-38$ & 49 & 44,5 \\
\hline & $39-45$ & 19 & 17,3 \\
\hline & 46 ve üstü & 8 & 7,3 \\
\hline \multirow{5}{*}{$\begin{array}{l}\text { Ĕgitim } \\
\text { Durumu }\end{array}$} & Lise & 10 & 9,1 \\
\hline & Önlisans & 8 & 7,3 \\
\hline & Lisans & 88 & 80,0 \\
\hline & Yüksek & 4 & 3,6 \\
\hline & Lisans/Doktora & & \\
\hline \multirow{5}{*}{$\begin{array}{l}\text { Kurumda } \\
\text { Çalışma Süresi }\end{array}$} & 1 Yıldan az & 8 & 7,3 \\
\hline & 6-10 & 64 & 58,2 \\
\hline & 11-15 & 22 & 20,0 \\
\hline & $16-20$ & 6 & 5,5 \\
\hline & 21 ve üstü & 10 & 9,1 \\
\hline
\end{tabular}

Tablo 2'deki sonuçlar incelendiğinde katılımcıların \%61,8'inin kadın, \%38,2'sinin erkek olduğu belirlenmiştir. Ayrıca katılımcıların yaşları incelendiğinde çoğunluğunun \%44,5 yüzde ile 32-38 yaş arası olduğu saptanmıştır. Eğitim düzeylerinin çoğu lisans olmakla beraber kurumda çalışma süresinin 6-10 yıl arasında yoğunlukta olduğu gözlemlenmektedir. 
Tablo 3: Basıklık-Çarpıklık Değerleri

\begin{tabular}{lll} 
& Basıklık & Çarpıklık \\
\hline İşe Tutkunluk &,- 396 &, 298 \\
Örgütsel Davranış &,- 091 &, 686 \\
\hline
\end{tabular}

Tablo 3'te ölçekte bulunan ifadelerin basıklık ve çarpıklık değerleri belirtilmiştir. Yapılan analiz sonucunda işe tutkunluk değişkeni için basıklık değerinin (-,396), çarpıklık değerinin $(, 298)$ ve örgütsel vatandaşlık değişkeni için basıklık değerinin (-,091), çarpıklık değerinin $(, 686)$ olduğu tespit edilmiştir. $\mathrm{Bu}$ bulgular verilerin normal dağıldığını ve ifadelerin kabul edilebilir olduğunu göstermektedir.

Tablo 4: İşe Tutkunluğun Alt Boyutlarıyla Örgütsel Vatandaşlığa İlişkin Korelasyon Analizi

\begin{tabular}{|c|c|c|c|c|c|c|}
\hline & & Dinçlik & Adanmışlık & Yoğunlaşma & $\begin{array}{l}\text { Örgütsel } \\
\text { Vatandaşlık }\end{array}$ & İşe Tutkunluk \\
\hline \multirow{3}{*}{ Dinçlik } & $\begin{array}{l}\text { Pearson } \\
\text { Correlation }\end{array}$ & 1 & & & & \\
\hline & Sig. & - & & & & \\
\hline & $\mathrm{N}$ & 110 & & & & \\
\hline \multirow{3}{*}{ Adanmışlık } & $\begin{array}{l}\text { Pearson } \\
\text { Correlation }\end{array}$ &, $381 * *$ & 1 & & & \\
\hline & Sig. &, 000 & - & & & \\
\hline & $\mathrm{N}$ & 110 & 110 & & & \\
\hline \multirow{3}{*}{ Yoğunlaşma } & $\begin{array}{l}\text { Pearson } \\
\text { Correlation }\end{array}$ &, $095^{* *}$ &, $535^{* *}$ & 1 & & \\
\hline & Sig. & ,322 & ,000 & - & & \\
\hline & $\mathrm{N}$ & 110 & 110 & 110 & & \\
\hline \multirow{3}{*}{$\begin{array}{l}\text { Örgütsel } \\
\text { Vatandaşlık }\end{array}$} & $\begin{array}{l}\text { Pearson } \\
\text { Correlation }\end{array}$ &, $412 * *$ &, 032 &,- 070 & 1 & \\
\hline & Sig. & ,000 & ,741 & 469 & - & \\
\hline & $\mathrm{N}$ & 110 & 110 & 110 & 110 & \\
\hline \multirow{3}{*}{ İşe Tutkunluk } & $\begin{array}{l}\text { Pearson } \\
\text { Correlation } \\
\end{array}$ &, $692 * *$ & $883 * *$ &, $654 * *$ &, 183 & 1 \\
\hline & Sig. & ,000 & ,000 & ,000 & ,056 & - \\
\hline & $\mathrm{N}$ & 110 & 110 & 110 & 110 & 110 \\
\hline
\end{tabular}

$* * \mathbf{p}<0.01, * \mathbf{p}<0.05$

Tablo 4'te verilen sonuçlara göre anlamlılık oranı (Sig.2tailed) 0,05 'ten küçük olduğu için işe tutkunluğun bir alt boyutu olan dinçlik ile örgütsel vatandaşlık davranışı arasında pozitif yönlü ve anlamlı bir ilişki tespit edilmiştir. $\mathrm{Bu}$ sonuca göre $\left(\mathbf{H}_{1}\right.$ : İşe tutkunluğun bir alt boyutu olan dinçlik ile örgütsel vatandaşlık arasında anlamlı bir ilişki vardır.) hipotezi kabul edilmiştir. Fakat işe tutkunluğun diğer alt boyutlarından yoğunlaşma ve adanmışlık ile örgütsel vatandaşlık davranışı arasından (Sig.2-tailed) 0,05'ten büyük olduğu için anlamlı bir ilişki bulunamamıştır. $\mathrm{Bu}$ sonuca göre $\mathbf{H}_{2}$ ve $\mathbf{H}_{3}$ hipotezleri reddedilmiştir.

Tablo 5: Anova Tablosu

\begin{tabular}{llllll}
\hline Model & $\mathbf{R}$ & $\mathbf{R}^{2}$ & Düzeltilmiş $\mathbf{R}^{\mathbf{2}}$ & $\begin{array}{l}\text { Anova } \\
\text { F }\end{array}$ & Sig. \\
& & & & 8,261 & 0,000 \\
\hline
\end{tabular}

*Bağımlı Değişken: Örgütsel Vatandaşlık Davranışı

Tablo 5'teki Anova tablosunda modelin anlamlılığı bağıml değişkendeki (örgütsel vatandaşlık davranışı) varyansın model tarafından ne kadar iyi açıklandığını belirtir. Tablodaki anlamlılık değeri (Sig.) 0.05 değerinden küçük olduğu için regresyon modeli istatistiksel olarak anlamlı bulunmuştur $(\mathrm{p}<0,001)$.

Tablo 6: İşe Tutkunluk ve Örgütsel Vatandaşlık Davranışı Arasındaki Regresyon Analizi

\begin{tabular}{llllll}
\hline Model & B & $\begin{array}{l}\text { Std. } \\
\text { Hata }\end{array}$ & $\boldsymbol{\beta}$ & T & Sig. \\
\cline { 3 - 6 } & & & & & \\
\hline Sabit & 3,633 & 0,223 & & 16,313 & 0,000 \\
\hline $\begin{array}{l}\text { İșe } \\
\text { Tutkunluk }\end{array}$ & 0,132 & 0,068 & 0,183 & 1,929 & 0,056 \\
\hline
\end{tabular}

Bağımlı Değişken: Örgütsel Vatandaşlık

Tablo 6'da belirtilen Sig. Değeri 0,005 değerinden büyük olduğu için $(0,056)$ işe tutkunluğun örgütsel vatandaşlik davranışı üzerinde anlamlı bir etkisi bulunamamıştır. Bu durumda $\mathrm{H}_{4}$ hipotezi reddedilmiştir. 
Tablo 7: İşe Tutkunluk ve Alt Boyutları İle Örgütsel Vatandaşlık Davranışı Arasındaki Çoklu Regresyon Analizi

\begin{tabular}{lllllllll}
\hline Model & B & Std. Hata & $\boldsymbol{\beta}$ & T & Sig. & & \\
& & & & & & & Tolerance & VIF \\
Sabit & 3,112 & 0,242 & & 12,863 & 0,000 & & \\
Yoğunlaşma & 0,009 & 0,073 & 0,018 & 0,121 & 0,904 & 0,329 & 3,039 \\
Dinçlik & 0,378 & 0,108 & 0,560 & 3,503 & 0,001 & 0,300 & 3,338 \\
Adanmışık & $-0,156$ & 0,151 & $-0,217$ & $-1,031$ & 0,305 & 0,173 & 5,774 \\
\hline
\end{tabular}

Bağımsız Değişkenler: Dinçlik, Adanmışlık, Yoğunlaşma $\quad$ Bağımlı Değişken: Örgütsel Vatandaşlık

Tablo 7 örgütsel vatandaşlık davranışının ne kadarının işe tutkunluğun alt boyutları olan adanmışlık, yoğunlaşma, dinçlik tarafından belirlendiğini tanımlayabilmek amacıyla çoklu regresyon analizi yapılmıştır. Bağımlı değişken örgütsel vatandaşlık davranışı ile bağımsız değişkenlerden sadece dinçlik arasında pozitif yönlü anlamlı ilişki bulunmuştur. Modele göre dinçlik boyutunda gerçekleşen bir birimlik artış diğer değişkenler sabitken örgütsel vatandaşlık davranışında 0,560 birimlik artışa neden olmaktadır. Elde edilen sonuçlar çerçevesinde işe tutkunluğun bir alt boyutu olarak kabul edilen dinçliğin örgütsel vatandaşlığa etkisi olduğu saptanmıştır. İşgörenin çalışma ortamında kendini enerjik hissetmesi iş performansı ve örgütsel vatandaşlık davranışını artıracaktır.

\section{Sonuç ve Öneriler}

Araştırmaya katılanların çoğunluğu 32-38 yaş aralığında, kurumda 6-10 yıl arasında çalışmakta olan, lisans eğitimi düzeyinde ve kadın banka personelleridir.

Yapılan analizler neticesinde işe tutkunluğun bir alt boyutu olan dinçlik ile örgütsel vatandaşlık davranışı arasında pozitif yönde anlamlı ilişkiler bulunmuştur. Bu sonuca göre $\left(\mathrm{H}_{1}\right.$ : İşe tutkunluğun bir alt boyutu olan dinçlik ile örgütsel vatandaşlık arasında anlamlı bir ilişki vardır.) hipotezi kabul edilmiştir. Ancak işe tutkunluğu diğer alt boyutlarından olan yoğunlaşma ve adanmışlık ile örgütsel vatandaşlık davranışı arasında anlamlı ilişkiler bulunamamıştır. Dinçlik arttığı zaman örgütsel vatandaşlık davranışının da arttığı tam tersi dinçlik kavramı azaldığında örgütsel vatandaşlık davranışının da azaldığı belirlenmiştir. $\mathrm{Bu}$ iki değişkenden birinin artırılmasına yönelik gerçekleştirilen faaliyetlerin diğer değişkeni de arttırdığı tespit edilmiştir.

Yapılan basit regresyon analizi neticesinde işe tutkunluğun örgütsel vatandaşlık davranışı üzerinde anlamlı bir etkisi bulunamamıştır. $\mathrm{Bu}$ sonuca göre $\left(\mathrm{H}_{4}\right.$ : İşe tutkunluğun örgütsel vatandaşlık davranışı üzerinde anlamlı bir etkisi vardır.) hipotezi reddedilmiştir. Çoklu regresyon analizi neticesine göre ise bağımlı değișken örgütsel vatandaşlığ açıklamada sadece dinçlik alt boyutunun anlamlı etkisi vardir $(\beta=0,560, \mathrm{p}<0,01)$. Elde edilen bulgulara göre $\left(\mathrm{H}_{4 \mathrm{a}}\right.$ : İşe tutkunluğun bir alt boyutu olan dinçliğin örgütsel vatandaşlık davranışı üzerinde anlamlı bir etkisi vardır.) hipotezi kabul edilmiştir. Diğer iki bağımsız değişkenden yoğunlaşma $(\beta=0,018, p>0,01)$ ile adanmışlığın $(\beta=$ $0,217, p>0,01)$ anlamlı katkısı yoktur. Analiz sonuçlarına gör $\mathrm{H}_{4 b}$ ve $\mathrm{H}_{4 c}$ hipotezleri reddedilmiştir. Örgütsel vatandaşlık davranışı ve işe tutkunluk kavramlarının bir örgütte arttırılması için çalışanlara kendilerini güvende hissedebilecekleri çalışma ortamı, destekleyici eğitim fırsatları, kendilerini geliştirme olanakları sunulmalıdır. Dinçlik duygusuna sahip banka çalışanlarının daha çok örgütsel vatandaşlık davranışı gerçekleştirdikleri görülmüştür. Yani kendilerinden talep edilen çalışma performansının üstüne çıkabilmişlerdir.

Anova tablosunda buluna $\mathrm{R}^{2}$ değeri $(0,189)$ 'a göre örgütsel vatandaşlık davranışındaki \%18 oranındaki varyansın dinçlik, adanmışlık ve yoğunlaşma alt boyutları tarafından açıklandığını gösterir. Ancak, Beta katsayıları incelendiğinde, tüm bağımsız değişkenler modele sokulduğu zaman yalnızca dinçlik alt boyutunun örgütsel vatandaşlık davranışını açıklamada anlamlı katkısının olduğu görülmektedir.

İnsan, işletmeler için önemli bir faktör olarak görülmektedir. Çalışanların başarılı olabilmeleri için belirli eğitimlerden geçmesi ve kendi çabalarını da dâhil ederek bu iki kavramın artması için gayret göstermeleri gereklidir (Kaplanseren, Örücü, 2018). İşe tutkunluk ve örgütsel vatandaşlık davranışı bu faktörleri arttırarak işgörenleri çalıştıkları örgütün adına tanımlanmış iş rollerinin de ötesine geçirerek faydalı faaliyetlerde bulunmalarını sağlayacaktır. $\mathrm{Bu}$ sebeplerden dolayı işe tutkunluk ve örgütsel vatandaşlığı arttırmak için kurumların çalışmalarda bulunması gereklidir. Kurumsal kaynaklar örgütün yararına kullanılır ve işgörenin eğitimine önem verilirse, kendilerine geliştirmeleri için olanaklar tanınırsa iki değişkende artış sağlanabilir. Öz yeterliliği ve özsaygısı gelişen işgören, çalıştığı kuruma daha çok bağlanacak ve çalışma şevki de yükselecektir. Personel güçlendirilirse, yetkisi arttırılırsa işgören üzerindeki baskı ve stres azalacak, işe tutkunluk ve örgütsel vatandaşlık artacaktır.

Dinçlik, işgörenin yorulmadan enerjik halde hem fiziki hem de zihnen çalıştığı örgütte koşullara uyum sağlamasıdır. Çalışan zor durumda kalsa dahi işini yapmaya devam eder. Böylece yaratıcılı hissi artar ve başarı yükselir. Yöneticilerin çalışanlarının dinçlik boyutunu geliştirmeleri sadece psikolojik yönüyle değil fiziksel yönüyle de ilgilenmelerini gerektirir. Banka çalışanları haricinde imalat sektörü çalışanlarında da araştırmanın yinelenmesinde yarar vardır. İşgörenlerin kendilerini daha dinç hissetmeleri için çalıştıkları ortamda konforun sağlanması gereklidir. Bunun yanısıra dinlenme araları uygun aralıklarla yapılmalı, çalışma süreleri normalin üstünde olmamalı, işyerlerine ulaşımları için gerekli imkânlar tanınmalıdır. 
$\mathrm{Bu}$ araştırma Bandırma ilçesinde bulunan 11 bankanın 110 çalışanı arasında yapıldığı için hem örneklem sayısının kısıtlı olması hem de belli sınırlar içerisinde yapılması bakımında belirli kısıtlara sahiptir. Örneklem sayısı arttırılarak daha faydalı sonuçlar elde edilebilir.

\section{Kaynakça}

Avcı, A. (2015). Örgütsel Vatandaşlık Davranışları: Kavramsal Gelişimi ve Eğitim Örgütleri Açısından Etkileri. Hasan Ali Yücel Eğitim Fakültesi Dergisi, 12(2), 11-26.

Bakker, A., \& Demerout1, E. (2012). Work Engagement, Performance and Active Learning: The Role of Conscientiousness. Journal of Vocational Behavior, 80(2), 555-564.

Başoda, A. (2017). İşe Tutkunluk: Kavramsal Açıdan Bir İnceleme. Tarihin Peşinde, 17, 71-95.

Christian,M.,\&Truss.(2011).Work Engagement: A Quantita tive Review and Test of Its Relations with Task and C ontextual Performance. Personnel Psychology, 10(1), 89-136.

Çankır, B. (2016). Çalışmaya Tutkunluğun Örgütsel Vatandaşlık Davranışı Üzerine Etkisi ve Bir Araştırma. Uluslararası Sosyal Araştırmalar Dergisi , 61(4), 766-773.

Çimen, M. (2016). Yönetimde Yeni Yaklaşımlar: Örgütsel Vatandaşlık Davranışı . Acıbadem Üniversitesi, Sağlık Bilimleri Fakültesi Dergisi, 1, 1-5.

Gic1 A., ve Tabancal1, E. (2011). The Level of Organizational Commitment of English Instructors Who Work in Preparatory School at Private Universities in European Part of Istanbul. 6th International Balkan Education and Science Congress, Macedonia.

Gürbüz, S., ve Şahin, F. (2017). Sosyal Bilimlerde Araştırma Yöntemleri, Ankara: Seçkin Yayıncılık.

Kaplanseren, S., \& Örücü, E. (2018). İşe Tutkunluğun Örgütsel Vatandaşlığa Etkisi: Otel Çalışanları Üzerine Bir Araştırma. Trakya Üniversitesi Íktisadi ve Ídari Bilimler Fakültesi Dergisi, 7(1), 1-21.

Karaarslan, A., Özler, D., \& Kulaklıŏlu, A. (2009). Örgütsel Vatandaşlık Davranışı ve Bilgi Paylaşımı Arasındaki İlişkiye Yönelik Bir Araştırma. Afyon Kocatepe Üniversitesi, I.I.B.F. Dergisi , 11(2), 136162.

Kataria, A., Garg, P., \& Rastogi, R. (2013). Does psychological climate augment OCBs? The Mediating Role of Work Engagement. The PsychologistManager Journal, 6, 217-242 .

Lyu, Y., Zhu, H., Zhong, H., \& Hu, L. (2016). Abusive Supervision and Customer-oriented Organizational Citizenship Behavior: The Roles of Hostile Attribution bias and Work Engagement. International Journal of Hospitality Management, 53, 69-80.

May,D.(2004).The Psychological Conditions of Meaningful ness, Safety and Availability and the Engagement of $t$ he Human Spirit at Work,Journal of Occupational and Organizational Psychology, 11(3), 11-37.

Meng, Y. S, Qui, S. H. \& Li, L. (2011). A Study on the Impact of the Hotels Leaders Psychological Capital on Employess Engagement. ICSSSM International Conference, 1-5.

Muçaoğlu, D. (2006). Çalışanların Arkadaşlık, Başarı ve Statü Çabaları ve Bu Çabaların Örgütsel Vatandaşlık Davranışlarıyla İlişkisinin İncelenmesi. Ankara: Yayımlanmamış Yüksek Lisans Tezi. Hacettepe Üniversitesi, Sosyal Bilimler Enstitüsü.

Organ, D. (1998). Organizational Citizenship Behavior: The Good Soldier Syndrome. Lexington, MA: Lexington Books. içinde

Özdevecioğlu, M. (2003). Örgütsel Vatandaşlık Davranışı ile Üniversite Öğrencilerinin Bazı Demografik Özellikleri ve Akademik Başarıları Arasındaki İlişkilerin Belirlenmesine Yönelik Bir Araştırma. Erciyes Üniversitesi IIBBF Dergisi, 20, 117-135.

Podsakoff, P. M., MacKenzie, S. B. \& Hui, (1993). Organizational Citizenship Behaviors and Managerial Evaluation of Employees' Performanca: A Review and Suggestions for Future Research. Open Journal of Leadership, 11(4), 1-40.

Runhaar, P., Konermann, J. \& Sanders, K., (2013). Teachers' Organizational Citizenship Behaviour: Considering the Roles of Their Work Engagement, Autonomy and Leader-Member Exchange. Teaching and Tecaher Education, 30(1), 99-108.

Salanova, M., Agut, S., \& Peiro, J. (2005). Linking Organizational Resources and Work Engagement to Employee Performance and Customer Loyalty: The Mediation of Service Climate. Journal of Applied Psychology, 90(6), 1218.

Schaufeli, W. B., \& Bakker, A. F (2003). Utretcht Work Engagement Scale, Preliminary Manual. Utrecht: Occupational Health Psychology Unit, Utrecht University.

Sezgin, F. (2005). Örgütsel Vatandaşlık Davranışları: Kavramsal Bir Çözümleme ve Okul Açısından Bazı Çıkarımlar. Gazi Ĕgitim Fakültesi Dergisi, 25(1), 317 339.

Shuck, B., Reio, T. G., ve Rocco, T. S. (2011). Employee Engagement: An Examination of Antecede nt and Outcome Variables. Human Resource Develop ment International, 14(4), 427-445.

Turgut, T. (2010). Çalışmaya Tutkunluk. Nobel, 57-89.

Ünüvar, T. (2006). An Integrative Model Of Job Characteristics, Job Satisfaction, Organızational Commitment, and Organizational Citizenship Behavior. Ortadoğu Teknik Üniversitesi, Sosyal Bilimler Enstitüsü, Yayımlanmamış Doktora Tezi.

Wilmar, B., ve Arnold, B. (2004). Job Demands, Job Resources and Their Relationship with Burnout and Engagement: A Multisample Study. Journal of Organizational Behavior, 25, 294. 